IZA DP No. 9598

Can Admissions Percent Plans Lead to Better Collegiate Fit for Minority Students?

Kalena E. Cortes

Jane Arnold Lincove

December 2015 


\title{
Can Admissions Percent Plans Lead to Better Collegiate Fit for Minority Students?
}

\author{
Kalena E. Cortes \\ Texas A\&M University, \\ NBER and IZA \\ Jane Arnold Lincove \\ Tulane University
}

Discussion Paper No. 9598

December 2015

\author{
IZA \\ P.O. Box 7240 \\ 53072 Bonn \\ Germany \\ Phone: +49-228-3894-0 \\ Fax: +49-228-3894-180 \\ E-mail: iza@iza.org
}

Any opinions expressed here are those of the author(s) and not those of IZA. Research published in this series may include views on policy, but the institute itself takes no institutional policy positions. The IZA research network is committed to the IZA Guiding Principles of Research Integrity.

The Institute for the Study of Labor (IZA) in Bonn is a local and virtual international research center and a place of communication between science, politics and business. IZA is an independent nonprofit organization supported by Deutsche Post Foundation. The center is associated with the University of Bonn and offers a stimulating research environment through its international network, workshops and conferences, data service, project support, research visits and doctoral program. IZA engages in (i) original and internationally competitive research in all fields of labor economics, (ii) development of policy concepts, and (iii) dissemination of research results and concepts to the interested public.

IZA Discussion Papers often represent preliminary work and are circulated to encourage discussion. Citation of such a paper should account for its provisional character. A revised version may be available directly from the author. 
IZA Discussion Paper No. 9598

December 2015

\section{ABSTRACT \\ Can Admissions Percent Plans Lead to Better Collegiate Fit for Minority Students?*}

Why do so many students mismatch when choosing a college? A plausible hypothesis is a lack of information about the likelihood of admission. This study contributes to the literature on mismatch by testing whether public university automatic admissions policies mitigate academic undermatch and promote academic overmatch by providing some students with admissions certainty. Focusing on the interaction of admissions certainty and race/ethnicity, our results support the hypothesis that a priori admissions information can vastly improve minority access to college quality by encouraging eligible students to apply to, and more importantly, enroll in more challenging institutions.

JEL Classification: I21, I23, J15

Keywords: academic undermatching and overmatching, admissions policies, Texas Top 10\% Plan, automatic admissions, college enrollment

Corresponding author:

Kalena E. Cortes

The Bush School of Government and Public Service

Texas A\&M University

4220 Tamu, 1049 Allen Building

College Station, TX 77843

USA

E-mail: kcortes@tamu.edu

\footnotetext{
* Special thanks to Sandra E. Black for all her encouragement and most valued advice. We are grateful to the Texas Workforce Data Quality Initiative at the University of Texas at Austin's Ray Marshall Center, funded by the U.S. Department of Labor. This research uses confidential data from the State of Texas supplied by the Texas Education Research Center (ERC) at UT-Austin. We gratefully acknowledge the use of these data. The views expressed are those of the authors and not the ERC or any of the funders or supporting organizations mentioned herein, including UT-Austin, Texas A\&M University, the Greater Texas Foundation, the State of Texas, or the study's sponsor. Any errors are attributable to the authors. We also thank Celeste Alexander from the ERC, and Matt Farber, Katherine Keiser, and Chester Polson who provided outstanding research assistance. Institutional support from UT-Austin, Texas A\&M University, and Tulane University are also gratefully acknowledged.
} 


\section{INTRODUCTION}

One of the most important decisions we make in life is where to go to college. Ideally, we want students to choose a college that maximizes not only their academic success but also their social well-being and lifetime earnings potential. However, past studies have documented the phenomena of both undermatch and overmatch — whereby some high-achieving students fail to enroll at highly selective colleges while some low-achieving students do enroll at these institutions (Black and Smith 2004; Light and Strayer 2004; Dillon and Smith 2015). Recent studies have focused on high-achieving, low-income students and find substantial undermatching among highly qualified students with low family resources (Griffith and Rothstein 2009; Hoxby and Avery 2013; Hoxby and Turner 2013; Smith, Penter, and Howell 2013). These students, who face the greatest potential for social mobility, fail to apply to prestigious universities despite the availability of generous financial aid. Black, Cortes, and Lincove (2015a; 2015b) also find concerning racial and ethnic differences in college application behavior, with Hispanics less likely to apply to college overall and blacks more likely to undermatch in college applications than white students.

The general consensuses in the student-college fit literature is that most of the observed mismatch stems from the application behavior of students, and not from the admission decisions by colleges (Dillon and Smith 2015). A plausible explanation for the observed mismatch among students is a lack of information about college quality and admissions processes (Hoxby and Avery 2013). In particular, low-income and minority students whose parents did not attend college might lack information about their prospects for acceptance, compared to more affluent white students with college-educated parents. If this hypothesis is correct, public university automatic admissions policies, which provide a priori information about the likelihood of acceptance, might improve minority students' college matching. 
Our study contributes to the existing research on student-college matching by examining mismatch in a setting where some students have perfect admissions information due to a state policy in Texas. We examine college enrollment behavior of two cohorts of high school graduates, which include large minority populations. These students were subject to a unique state policy, the Top 10\% Plan, which provides perfect information about college admissions well in advance of application. Texas was among the first states to implement an admissions "percent plan" and is the only state that grants automatic admissions solely on the basis of class rank (Black, Cortes, and Lincove forthcoming). Specifically, the policy guarantees admission into any Texas public university to all high school seniors who finish their junior year within the top decile of their high school graduating class. Also, unlike other percent plans, Texas offers institutional choiceincluding to the highly selective flagship campuses of the University of Texas at Austin and Texas A\&M University, whereas under other states’ percent plans, the university-wide system assigns the campus. Given that admissions under this percent plan is based on class rank alone and also provides institutional choice, the Top $10 \%$ Plan has both the potential to mitigate undermatch in high-achieving students by providing perfect information about admissions to their choice of institution, as well as to exacerbate overmatch in students with low college readiness by providing automatic admissions based solely on class rank regardless of all other measures of college qualifications.

Relative to the existing research on student-college fit, our analysis here provides several new insights. First, we are able to directly examine the role of admissions information in college matching decisions in enrollment. We do this by comparing academic mismatch behavior of otherwise similar students who are and are not eligible for automatic admissions. Second, because Texas's automatic admissions policy admits students based on class rank alone, we are also able 
to observe college choices for students not previously studied - those with automatic admissions through having achieved a high class rank, but also low college readiness as measured by SAT or ACT exams. This enables analysis of both undermatch and overmatch. Our results support the hypothesis that a priori admissions information can vastly improve minority access to college quality by encouraging eligible students to apply to, and more importantly, enroll in more challenging institutions.

\section{DATA SOURCES}

We use restricted student-college matched administrative data for all Texas public university enrollees who graduated from a Texas public high school in 2008 and 2009, provided through the Education Research Center (ERC) at the University of Texas at Austin. High school measures of college readiness (SAT or ACT equivalent, exit exam scores, and advanced placement courses completed) and eligibility for automatic admissions were obtained from each student's high school academic records and college applications. Student demographics and family income were obtained from high school enrollment records, college applications, and financial aid forms.

The outcome of interest in this study is academic match quality, as measured by the distance between a student's SAT score (or ACT equivalent) and the campus median where she ultimately enrolled. We used merged college application and enrollment files to calculate the statewide SAT percentile ranks for all college applicants and to place individual students and campus medians within the state distribution. We define overmatch and undermatch based on the difference between a student's SAT percentile and the percentile of the campus' median SAT score. ${ }^{1}$ Undermatch occurs if the student's SAT score is more than 20 percentile points above the lagged campus median, and overmatch occurs if the student's SAT score is more than 20 percentile

\footnotetext{
${ }^{1}$ Our overmatch and undermatch classification is based on Dillon and Smith’s (2015) definition.
} 
points below the lagged campus median. Campus aggregates were calculated based on enrollment in the year prior to each student's high school graduation to reflect how the student would observe the campus in the year she applied to college.

\section{EMPIRICAL FINDINGS AND DISCUSSION}

Table 1 presents summary statistics for the full sample of enrollees (panel A) and by enrollees' race and ethnicity (panel B). Among all enrollees, approximately 19 percent of the sample is overmatched by more than 20 SAT percentile points, and 18 percent of the sample is undermatched. However, there is a distinct pattern of college mismatch by race and ethnicity. Overmatch rates among black and Hispanic students are 29 and 25 percent, respectively, while overmatch rates for Asian and white students are only 15 and 13 percent, respectively. In terms of undermatch, we observe the reverse pattern: black and Hispanic students undermatch in college enrollment by only 9 and 15 percent, respectively, compared to 18 percent of Asian and 22 percent of white students. At the same time, black and Hispanic students attend high schools with lower average college readiness and college-going rates, and whites and Asians are more likely to benefit from automatic admissions. Thus, regression analysis with controls is needed to isolate the effects of automatic admissions, given that students from different racial and ethnic backgrounds vary in both college preparation and class rank.

Our empirical objective is to estimate the effects of race/ethnicity on the propensity to undermatch/overmatch and the mediating effects of a priori admissions information provided through the Top $10 \%$ admissions policy. We estimate the probability that a student mismatches in college enrollment as a function of race/ethnicity, admissions status (as observed through class rank), SAT percentile rank, other measures of college readiness (high school exit exam score and AP courses completed), and student demographics (gender, mother's education, and family 
income). We also include high school fixed effects to control for differences in high school quality, and thus we estimate on differences across students of different races/ethnicities from the same high school. We are able to identify three categories of admissions status - top 10\% students who are guaranteed admissions and have full admissions certainty, top 11-25\% students who have a high probability of admissions in a holistic review process, and bottom $75 \%$ students who have a less likely admissions status. Because admissions certainty might operate differently for low- and high-achieving students, we also estimate the probability of undermatch for students with high SAT scores (top 25\% statewide) and the probability of overmatch for students with low SAT scores (bottom 25\% statewide). We then add interaction terms for race/ethnicity and class rank to see if automatic or likely admissions affects matching differently for minority students.

Table 2 presents the Ordinary Least Squares regression results predicting the probability that a student undermatches or overmatches in college enrollment versus attending a well-matched institution. As shown in column (1) of Table 2, in the full enrollment sample (panel A), the probability of undermatch is reduced by 13.6 percentage points for a top $10 \%$ student and 3.2 percentage points for a top $11-25 \%$ student, relative to a similar student in the bottom $75 \%$ at the same high school. The comparison between the top 10\% and the reference group (bottom 75\%) measures the combined effect of perfect admissions information and higher class rank, while the comparison between top 11-25\% and the reference group provides the stand-alone effect of higher class rank without guaranteed admissions. The results in column (1) indicate that, ceteris paribus, black students are significantly more likely to undermatch than whites by 6 percentage points. The within-high school difference between Hispanics and white students is not statistically significant, and Asians are significantly less likely to undermatch than white students. 
In column (2) of Table 2, we add interactions between race/ethnicity and class rank to the specification on the full sample. Despite guaranteed admissions, top $10 \%$ students who are black or Hispanic are significantly more likely to undermatch in college enrollment by 2.7 and 6.8 percentage points than white top $10 \%$ students from the same high school, while Asian top $10 \%$ students are less likely to undermatch than whites by 7.4 percentage points. Looking at students with uncertain admissions, top 11-25\% black students are less likely to undermatch by 1.7 percentage points, but Hispanic students continue to undermatch by 2.4 percentage points compared to similar white top $11-25 \%$ students. Top $11-25 \%$ students are an interesting group because these students underwent a more traditional holistic admissions process that included race/ethnicity as one of many background factors. Interestingly, black undermatch is less likely for these students who undergo holistic admissions, but admissions that considers ethnicity is no help for Hispanic students who are top 11-25\%. Nevertheless, it is quite worrisome that black and Hispanic top $10 \%$ students, who have full information regarding their admissions prospects at better-matched institutions, are more likely to undermatch in college enrollment.

A tenant of the Top $10 \%$ Plan is that admissions is solely based on class rank regardless of students' college preparedness. Thus, by dividing our sample by SAT performance, we can better identify the dynamics of admissions policy and race/ethnicity for groups of students who have a similar choice set of well-matched vs. mismatched institutions. Panels B and C of Table 2 show regression results by SAT quartile to provide insight into whether the Top 10\% Plan decreases undermatching for the top SAT quartile or increases overmatching for the bottom SAT quartile. As observed in column (3) of panel B, top 10\% students who have high SAT's are 32 percentage points less likely to undermatch relative to students who are ranked at the bottom $75 \%$. Within the high-SAT group, we see no significant differences for black and Hispanic students, and Asians are 
less likely to undermatch compared to whites, ceteris paribus. However, adding interactions for race/ethnicity and class rank (column (4)), we find significant negative interactions between top $10 \%$ and black, Hispanic, and Asian indicators. This suggests that among students with high SAT scores, automatic admissions reduces undermatch tendencies for minority students more than similar white students, potentially closing a gap in access to academically rigorous campuses.

Finally, we compare the effects of race/ethnicity and automatic admissions for students with low SATs who might overmatch in college enrollment due to the Top 10\% Plan. Without interaction terms (panel C, column (5)), we estimate that top 10\% students are more likely to overmatch by 24 percentage points, but black students are less likely to overmatch than whites by over 25 percentage points, ceteris paribus. Hispanics are less likely to overmatch than whites by a smaller, but still significant, 2-3 percentage point margin. Adding interactions for race/ethnicity and class rank (column (6)), we find that automatic admissions fully reverses the estimated gap between black and white students. The net effect of being black (-0.319) and in the top $10 \%$ $(+0.366)$ means that top $10 \%$ black and white students might have similar probabilities of overmatch, ceteris paribus. Coefficients for Hispanic and interaction terms between top $10 \%$ and Hispanic are not statistically significant, suggesting that Hispanics with low SATs behave toward undermatch in ways that are similar to white students, ceteris paribus.

\section{Concluding Remarks}

Racial and ethnic differences in college mismatch can derive from different levels of college preparation and high school quality or from different sources of information about college, different expectations from families and teachers, or different expectations about future success. In this study, we estimate racial and ethnic differences in college mismatch behavior that are robust to controls for demographics, observable college readiness, and high school attended. There are 
three main takeaways from this analysis. First, the phenomena of undermatch and overmatch can occur even if students have perfect information. Second, we find that automatic admissions mitigates some racial/ethnic differences in college mismatch behavior. Minority students who are eligible for automatic admissions often behave toward campus matching in ways that are more similar to whites than students who have uncertainty. We find that automatic admissions prevents black and Hispanic students with high SATs from undermatching and also encourages black students with low SATs to overmatch. Third, automatic admissions only mitigated minority undermatch when students also had high SAT scores. Thus, automatic admission policies interact with other signals in student enrollment decisions. Overall, our results support the hypothesis that perfect admissions information can improve college matching for high-performing minority students and also induce overmatching for low-performing minority students with high class rank. It is unclear if similar effects would occur if less-than-perfect signals of admissions were offered, as we typically find smaller effects of top 11-25\% class rank (likely admissions) than top 10\% (certain admissions).

\section{REFERENCES}

Black, Sandra E., Kalena E. Cortes, and Jane Arnold Lincove. Forthcoming. "Efficacy vs. Equity: What Happens When States Tinker with College Admissions in a Race-Blind Era?” Educational Evaluation and Policy Analysis.

Black, Sandra E., Kalena E. Cortes, and Jane Arnold Lincove. 2015a. “Academic Undermatching of High-Achieving Minority Students: Evidence from Race-Neutral and Holistic Admissions Policies.” American Economic Review, 105(5): 604-10.

Black, Sandra E., Kalena E. Cortes, and Jane Arnold Lincove. 2015b. “Apply Yourself: Racial and Ethnic Differences in College Application.” National Bureau of Economic Research Working Paper No. 21368.

Black, Dan and Jeffrey A. Smith. 2004. "How Robust is the Evidence on the Effects of College Quality? Evidence from Matching.” Journal of Econometrics 121(1): 99-124. 
Dillon, Eleanor W. and Jeffrey A. Smith. Forthcoming. "The Determinants of Mismatch between Students and Colleges.” Journal of Labor Economics.

Griffith, Amanda L., and Donna S. Rothstein. 2009. “Can’t Get There from Here: The Decision to Apply to a Selective College.” Economics of Education Review 28 (5): 620-28.

Hoxby, Caroline, and Christopher Avery. 2013. “The Missing 'One-Offs': The Hidden Supply of High-Achieving, Low-Income Students.” Brookings Papers on Economic Activity (Spring): 1-61.

Hoxby, Caroline, and Sarah Turner. 2013. "Expanding College Opportunities for HighAchieving Low-Income Students.” Stanford Institute for Economic Policy Research Discussion Paper No. 12-014.

Light, Audrey and Wayne Strayer. 2000. “Determinants of College Completion: School Quality or Student Ability?” Journal of Human Resources 35(2): 299-332.

Smith, Jonathan, Matea Pender, and Jessica Howell. 2013. "The Full Extent of StudentCollege Academic Undermatch.” Economics of Education Review 32: 247-61. 


\begin{tabular}{|c|c|c|c|c|c|}
\hline & \multirow{2}{*}{$\begin{array}{c}\text { Panel A: All } \\
\text { Enrollees }\end{array}$} & \multicolumn{4}{|c|}{ Panel B: Enrollees by Race and Ethnicity } \\
\hline & & Black & Hispanic & Asian & White \\
\hline \multicolumn{6}{|l|}{ SAT match quality of college campus ${ }^{a}$} \\
\hline Overmatched by 20 or more percentile points & $\begin{array}{c}0.185 \\
(0.388)\end{array}$ & $\begin{array}{c}0.289 \\
(0.453)\end{array}$ & $\begin{array}{c}0.249 \\
(0.432)\end{array}$ & $\begin{array}{c}0.149 \\
(0.356)\end{array}$ & $\begin{array}{c}0.129 \\
(0.335)\end{array}$ \\
\hline Undermatched by 20 or more percentile points & $\begin{array}{c}0.178 \\
(0.383)\end{array}$ & $\begin{array}{c}0.091 \\
(0.287)\end{array}$ & $\begin{array}{c}0.145 \\
(0.352)\end{array}$ & $\begin{array}{c}0.184 \\
(0.387)\end{array}$ & $\begin{array}{c}0.218 \\
(0.413)\end{array}$ \\
\hline \multicolumn{6}{|l|}{ Student's high school class rank } \\
\hline Top 10\%, guaranteed admissions & $\begin{array}{c}0.275 \\
(0.446)\end{array}$ & $\begin{array}{c}0.138 \\
(0.345)\end{array}$ & $\begin{array}{c}0.264 \\
(0.441)\end{array}$ & $\begin{array}{c}0.400 \\
(0.490)\end{array}$ & $\begin{array}{c}0.297 \\
(0.457)\end{array}$ \\
\hline Top 11-25\%, holistic admissions & $\begin{array}{c}0.227 \\
(0.419)\end{array}$ & $\begin{array}{c}0.176 \\
(0.381)\end{array}$ & $\begin{array}{c}0.244 \\
(0.429)\end{array}$ & $\begin{array}{c}0.166 \\
(0.372)\end{array}$ & $\begin{array}{c}0.240 \\
(0.427)\end{array}$ \\
\hline Bottom 75\% & $\begin{array}{c}0.499 \\
(0.500)\end{array}$ & $\begin{array}{c}0.686 \\
(0.464)\end{array}$ & $\begin{array}{c}0.492 \\
(0.500)\end{array}$ & $\begin{array}{c}0.434 \\
(0.496)\end{array}$ & $\begin{array}{c}0.463 \\
(0.499)\end{array}$ \\
\hline \multicolumn{6}{|l|}{ High school characteristics ${ }^{b}$} \\
\hline$\%$ Black & $\begin{array}{c}0.132 \\
(0.159)\end{array}$ & $\begin{array}{c}0.350 \\
(0.239)\end{array}$ & $\begin{array}{c}0.074 \\
(0.114)\end{array}$ & $\begin{array}{c}0.162 \\
(0.128)\end{array}$ & $\begin{array}{c}0.103 \\
(0.101)\end{array}$ \\
\hline \% Hispanic & $\begin{array}{c}0.393 \\
(0.288)\end{array}$ & $\begin{array}{c}0.333 \\
(0.190)\end{array}$ & $\begin{array}{c}0.688 \\
(0.294)\end{array}$ & $\begin{array}{c}0.282 \\
(0.188)\end{array}$ & $\begin{array}{c}0.265 \\
(0.184)\end{array}$ \\
\hline$\%$ Free and reduced lunch eligibility & $\begin{array}{c}0.393 \\
(0.247)\end{array}$ & $\begin{array}{c}0.479 \\
(0.211)\end{array}$ & $\begin{array}{c}0.589 \\
(0.257)\end{array}$ & $\begin{array}{c}0.287 \\
(0.197)\end{array}$ & $\begin{array}{c}0.281 \\
(0.171)\end{array}$ \\
\hline \% Took Advanced Placement (AP) test & $\begin{array}{c}0.237 \\
(0.147)\end{array}$ & $\begin{array}{c}0.202 \\
(0.130)\end{array}$ & $\begin{array}{c}0.226 \\
(0.139)\end{array}$ & $\begin{array}{c}0.286 \\
(0.146)\end{array}$ & $\begin{array}{c}0.244 \\
(0.152)\end{array}$ \\
\hline \% Enrolled at 4-year university & $\begin{array}{c}0.359 \\
(0.143)\end{array}$ & $\begin{array}{c}0.311 \\
(0.114)\end{array}$ & $\begin{array}{c}0.352 \\
(0.162)\end{array}$ & $\begin{array}{c}0.408 \\
(0.145)\end{array}$ & $\begin{array}{c}0.368 \\
(0.135)\end{array}$ \\
\hline Observations & 93,860 & 12,404 & 25,965 & 6,980 & 48,511 \\
\hline
\end{tabular}

Notes: Standard deviations are in parentheses. ${ }^{a}$ Student and campus SAT percentile are calculated based on all applicants to Texas public universities within each academic year. Overmatch and undermatch are identified based on the difference between the student's SAT percentile and percentile of the campus's median SAT score (lagged one year). Overmatch occurs if the student's SAT score is more than 20 points below the lagged campus median. Undermatch occurs if the student's SAT score is more than 20 above the lagged campus median. ${ }^{\mathrm{b} H i g h}$ school characteristics are measured during the student's junior year.

Source: Authors' calculations based on 2008 and 2009 student cohort data from the Texas Education Research Center (ERC) at the University of Texas at Austin. Our dataset includes Texas public high school graduates from spring 2008 and spring 2009 who also enrolled full-time at a Texas public university the following fall. The 2008 and 2009 high school graduates enrolled at one of 31 Texas public university including the elite flagship universities (University of Texas at Austin and Texas A\&M University at College Stations), other top $10 \%$ campuses, and open enrollment institutions. 


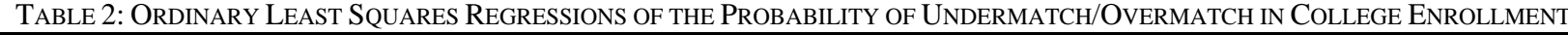

\begin{tabular}{|c|c|c|c|c|c|c|}
\hline & \multicolumn{2}{|c|}{$\begin{array}{c}\text { Panel A: Sample includes } \\
\text { all students } \text {, Undermatch } \\
\text { by } 20+\text { points }\end{array}$} & \multicolumn{2}{|c|}{$\begin{array}{l}\text { Panel B: Top } 25 \% \text { of } \\
\text { SAT }^{\text {b }} \text {, Undermatch } \\
\text { By } 20+\text { points }\end{array}$} & \multicolumn{2}{|c|}{$\begin{array}{c}\text { Panel C: Bottom } 25 \% \text { of } \\
\text { SAT }^{c} \text {, Overmatch by } \\
20+\text { points }\end{array}$} \\
\hline & (1) & $(2)$ & (3) & (4) & (5) & (6) \\
\hline \multicolumn{7}{|l|}{ High school class rank } \\
\hline Top 10\% student & $\begin{array}{c}-0.136 * * * \\
(0.003)\end{array}$ & $\begin{array}{c}-0.150 * * * \\
(0.004)\end{array}$ & $\begin{array}{c}-0.323 * * * \\
(0.008)\end{array}$ & $\begin{array}{c}-0.304^{* * *} \\
(0.009)\end{array}$ & $\begin{array}{c}0.242 * * * \\
(0.013)\end{array}$ & $\begin{array}{c}0.109 * * * \\
(0.034)\end{array}$ \\
\hline Top $11-25 \%$ student & $\begin{array}{c}-0.032 * * * \\
(0.003)\end{array}$ & $\begin{array}{c}-0.036 * * * \\
(0.004)\end{array}$ & $\begin{array}{c}-0.119 * * * \\
(0.008)\end{array}$ & $\begin{array}{c}-0.116^{* * *} \\
(0.010)\end{array}$ & $\begin{array}{c}0.153^{* * *} \\
(0.009)\end{array}$ & $\begin{array}{c}0.074 * * * \\
(0.020)\end{array}$ \\
\hline \multicolumn{7}{|l|}{ Race and ethnicity } \\
\hline Black & $\begin{array}{c}0.061 * * * \\
(0.004)\end{array}$ & $\begin{array}{c}0.058^{* * *} \\
(0.005)\end{array}$ & $\begin{array}{c}-0.009 \\
(0.018)\end{array}$ & $\begin{array}{c}0.042 \\
(0.026)\end{array}$ & $\begin{array}{c}-0.256^{* * *} \\
(0.013)\end{array}$ & $\begin{array}{c}-0.319 * * * \\
(0.014)\end{array}$ \\
\hline Hispanic & $\begin{array}{c}0.005 \\
(0.004)\end{array}$ & $\begin{array}{c}-0.017 * * * \\
(0.004)\end{array}$ & $\begin{array}{c}0.001 \\
(0.010)\end{array}$ & $\begin{array}{c}0.030 * \\
(0.017)\end{array}$ & $\begin{array}{c}-0.026^{* *} \\
(0.012)\end{array}$ & $\begin{array}{l}-0.019 \\
(0.013)\end{array}$ \\
\hline Asian & $\begin{array}{c}-0.034 * * * \\
(0.005)\end{array}$ & $\begin{array}{c}-0.002 \\
(0.007)\end{array}$ & $\begin{array}{c}-0.038 * * * \\
(0.010)\end{array}$ & $\begin{array}{c}-0.010 \\
(0.016)\end{array}$ & $\begin{array}{c}0.021 \\
(0.023)\end{array}$ & $\begin{array}{l}-0.049 * \\
(0.028)\end{array}$ \\
\hline \multicolumn{7}{|l|}{ Interactions with class rank } \\
\hline Top 10\% x Black & & $\begin{array}{c}0.027 * * * \\
(0.010)\end{array}$ & & $\begin{array}{c}-0.133 * * * \\
(0.039)\end{array}$ & & $\begin{array}{c}0.366^{* * *} \\
(0.040)\end{array}$ \\
\hline Top 10\% x Hispanic & & $\begin{array}{c}0.068 * * * \\
(0.006)\end{array}$ & & $\begin{array}{c}-0.064 * * * \\
(0.021)\end{array}$ & & $\begin{array}{c}0.032 \\
(0.037)\end{array}$ \\
\hline Top 10\% x Asian & & $\begin{array}{c}-0.074 * * * \\
(0.010)\end{array}$ & & $\begin{array}{c}-0.056^{* * *} \\
(0.019)\end{array}$ & & $\begin{array}{c}0.238 * * * \\
(0.066)\end{array}$ \\
\hline Top 11-25\% x Black & & $\begin{array}{c}-0.017 * \\
(0.009)\end{array}$ & & $\begin{array}{c}-0.013 \\
(0.046)\end{array}$ & & $\begin{array}{c}0.284 * * * \\
(0.026)\end{array}$ \\
\hline Top 11-25\% x Hispanic & & $\begin{array}{c}0.024 * * * \\
(0.006)\end{array}$ & & $\begin{array}{c}-0.003 \\
(0.025)\end{array}$ & & $\begin{array}{l}-0.003 \\
(0.023)\end{array}$ \\
\hline Top 11-25\% x Asian & & $\begin{array}{c}-0.003 \\
(0.012)\end{array}$ & & $\begin{array}{c}0.006 \\
(0.026)\end{array}$ & & $\begin{array}{c}0.189 * * * \\
(0.052)\end{array}$ \\
\hline \multicolumn{7}{|l|}{ College readiness } \\
\hline SAT percentile rank & $\begin{array}{c}0.956 * * * \\
(0.007)\end{array}$ & $\begin{array}{c}0.958 * * * \\
(0.007)\end{array}$ & $\begin{array}{c}0.795 * * * \\
(0.047)\end{array}$ & $\begin{array}{c}0.792 * * * \\
(0.047)\end{array}$ & $\begin{array}{c}-1.812 * * * \\
(0.052)\end{array}$ & $\begin{array}{c}-1.837 * * * \\
(0.051)\end{array}$ \\
\hline Exit exam percentile rank & $\begin{array}{c}-0.052 * * * \\
(0.007)\end{array}$ & $\begin{array}{c}-0.057^{* * *} \\
(0.007)\end{array}$ & $\begin{array}{c}-0.095 * * * \\
(0.022)\end{array}$ & $\begin{array}{c}-0.095 * * * \\
(0.022)\end{array}$ & $\begin{array}{c}0.115^{* * * *} \\
(0.018)\end{array}$ & $\begin{array}{c}0.120 * * * \\
(0.018)\end{array}$ \\
\hline AP semesters completed & $\begin{array}{c}-0.008^{* * *} \\
(0.000)\end{array}$ & $\begin{array}{c}-0.007^{* * *} \\
(0.000)\end{array}$ & $\begin{array}{c}-0.013 * * * \\
(0.001)\end{array}$ & $\begin{array}{c}-0.013 * * * \\
(0.001)\end{array}$ & $\begin{array}{c}0.010^{* * *} \\
(0.001)\end{array}$ & $\begin{array}{c}0.010 * * * \\
(0.001)\end{array}$ \\
\hline Observations & 93,860 & 93,860 & 25,842 & 25,842 & 18,066 & 18,066 \\
\hline $\mathrm{R}^{2}$ & 0.222 & 0.224 & 0.135 & 0.136 & 0.134 & 0.151 \\
\hline \multicolumn{7}{|l|}{ Other controls } \\
\hline Demographics $^{\mathrm{d}}$ & Yes & Yes & Yes & Yes & Yes & Yes \\
\hline High school fixed effects & Yes & Yes & Yes & Yes & Yes & Yes \\
\hline
\end{tabular}

Notes: Columns (1)-(6) show estimates from linear probability models of the probability of undermatch/overmatch in college enrollment. Undermatch occurs if the student's SAT score is more than 20 points above the lagged campus median. Overmatch occurs if the student's SAT

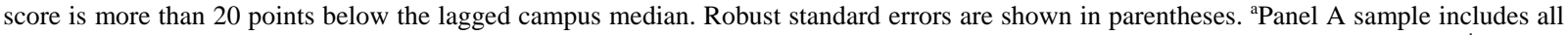
Texas public high school graduates from 2008 and 2009 who enrolled at a Texas public university (31 campuses) the following fall. ${ }^{b}$ Panel B sample includes a subset of students with SAT scores (or ACT equivalent) in the top $25 \%$ among public university applications statewide. ${ }^{~ P a n e l}$ C sample includes a subset of students with SAT scores (or ACT equivalent) in the bottom $25 \%$ among public university applications statewide. ${ }^{\mathrm{d}}$ Regressions also control for graduation year, gender, age, parental education, and family income. ${ }^{* *},{ }^{* *}, *$ indicates statistical significance at the $1 \%, 5 \%$, and $10 \%$ level, respectively. 


\title{
ONLINE APPENDiX
}

\section{Can Admissions Percent Plans Lead to Better Collegiate Fit FOR MINORITY STUDENTS?}

\author{
By Kalena E. Cortes and Jane ARnold Lincove*
}

\footnotetext{
* Cortes: The Bush School of Government and Public Service, 4220 TAMU, 1049 Allen Building, Texas A\&M University, College Station, TX 77843; Research Fellow at the Institute for the Study of Labor (IZA); and Faculty Research Fellow at the National Bureau of Economic Research (e-mail: kcortes@tamu.edu). Lincove: Department of Economics and Education Research Alliance for New Orleans, Tulane University (email: jlincove@tulane.edu). Special thanks to Sandra E. Black for all her encouragement and most valued advice. We are grateful to the Texas Workforce Data Quality Initiative at the University of Texas at Austin's Ray Marshall Center, funded by the U.S. Department of Labor. This research uses confidential data from the State of Texas supplied by the Texas Education Research Center (ERC) at UT-Austin. We gratefully acknowledge the use of these data. The views expressed are those of the authors and not the ERC or any of the funders or supporting organizations mentioned herein, including UT-Austin, Texas A\&M University, the Greater Texas Foundation, the State of Texas, or the study's sponsor. Any errors are attributable to the authors. We also thank Celeste Alexander from the ERC, and Matt Farber, Katherine Keiser, and Chester Polson who provided outstanding research assistance. Institutional support from UT-Austin, Texas A\&M University, and Tulane University are also gratefully acknowledged.
} 
APPENDIX TABLE: ORDINARY LEAST SQUARES REGRESSIONS OF THE PROBABILITY OF UNDERMATCH/OVERMATCH IN COLLEGE ENROLLMENT

\begin{tabular}{|c|c|c|c|c|c|c|}
\hline & \multicolumn{2}{|c|}{$\begin{array}{c}\text { Panel A: } \\
\text { Sample includes all } \\
\text { students }{ }^{\text {a }} \text {, Undermatch } \\
\text { by } 20+\text { points }\end{array}$} & \multicolumn{2}{|c|}{$\begin{array}{c}\text { Panel B: } \\
\text { Top 25\% of } \text { SAT }^{\mathrm{b}} \text {, } \\
\text { Undermatch by } 20+ \\
\text { points }\end{array}$} & \multicolumn{2}{|c|}{$\begin{array}{c}\text { Panel C: } \\
\text { Bottom } 25 \% \text { of } \text { SAT }^{\mathrm{c}} \text {, } \\
\text { Overmatch by } 20+ \\
\text { points }\end{array}$} \\
\hline & $(1)$ & $(2)$ & (3) & (4) & (5) & (6) \\
\hline \multicolumn{7}{|c|}{ High school class rank (bottom $75 \%$ is omitted) } \\
\hline Top 10\% student & $\begin{array}{c}-0.136^{* * *} \\
(0.003)\end{array}$ & $\begin{array}{c}-0.150 * * * \\
(0.004)\end{array}$ & $\begin{array}{c}-0.323^{* * *} \\
(0.008)\end{array}$ & $\begin{array}{c}-0.304^{* * *} \\
(0.009)\end{array}$ & $\begin{array}{c}0.242^{* * *} \\
(0.013)\end{array}$ & $\begin{array}{c}0.109 * * * \\
(0.034)\end{array}$ \\
\hline Top 11-25\% student & $\begin{array}{c}-0.032 * * * \\
(0.003)\end{array}$ & $\begin{array}{c}-0.036 * * * \\
(0.004)\end{array}$ & $\begin{array}{c}-0.119 * * * \\
(0.008)\end{array}$ & $\begin{array}{c}-0.116^{* * *} \\
(0.010)\end{array}$ & $\begin{array}{c}0.153^{* * *} \\
(0.009)\end{array}$ & $\begin{array}{c}0.074^{* * *} \\
(0.020)\end{array}$ \\
\hline \multicolumn{7}{|c|}{ Race and ethnicity (white is omitted) } \\
\hline Black & $\begin{array}{c}0.061^{* * *} \\
(0.004)\end{array}$ & $\begin{array}{c}0.058^{* * *} \\
(0.005)\end{array}$ & $\begin{array}{l}-0.009 \\
(0.018)\end{array}$ & $\begin{array}{c}0.042 \\
(0.026)\end{array}$ & $\begin{array}{c}-0.256 * * * \\
(0.013)\end{array}$ & $\begin{array}{c}-0.319 * * * \\
(0.014)\end{array}$ \\
\hline Hispanic & $\begin{array}{c}0.005 \\
(0.004)\end{array}$ & $\begin{array}{c}-0.017 * * * \\
(0.004)\end{array}$ & $\begin{array}{c}0.001 \\
(0.010)\end{array}$ & $\begin{array}{l}0.030 * \\
(0.017)\end{array}$ & $\begin{array}{c}-0.026^{* *} \\
(0.012)\end{array}$ & $\begin{array}{l}-0.019 \\
(0.013)\end{array}$ \\
\hline Asian & $\begin{array}{c}-0.034^{* * *} \\
(0.005)\end{array}$ & $\begin{array}{l}-0.002 \\
(0.007)\end{array}$ & $\begin{array}{c}-0.038^{* * *} \\
(0.010)\end{array}$ & $\begin{array}{l}-0.010 \\
(0.016)\end{array}$ & $\begin{array}{c}0.021 \\
(0.023)\end{array}$ & $\begin{array}{c}-0.049 * \\
(0.028)\end{array}$ \\
\hline \multicolumn{7}{|l|}{ Interactions with class rank } \\
\hline Top $10 \%$ x Black & & $\begin{array}{c}0.027 * * * \\
(0.010)\end{array}$ & & $\begin{array}{c}-0.133^{* * *} \\
(0.039)\end{array}$ & & $\begin{array}{c}0.366^{* * *} \\
(0.040)\end{array}$ \\
\hline Top 10\% x Hispanic & & $\begin{array}{c}0.068^{* * *} \\
(0.006)\end{array}$ & & $\begin{array}{c}-0.064^{* * *} \\
(0.021)\end{array}$ & & $\begin{array}{c}0.032 \\
(0.037)\end{array}$ \\
\hline Top 10\% x Asian & & $\begin{array}{c}-0.074 * * * \\
(0.010)\end{array}$ & & $\begin{array}{c}-0.056^{* * *} \\
(0.019)\end{array}$ & & $\begin{array}{c}0.238^{* * *} \\
(0.066)\end{array}$ \\
\hline Top 11-25\% x Black & & $\begin{array}{c}-0.017^{*} \\
(0.009)\end{array}$ & & $\begin{array}{l}-0.013 \\
(0.046)\end{array}$ & & $\begin{array}{c}0.284^{* * *} \\
(0.026)\end{array}$ \\
\hline Top 11-25\% x Hispanic & & $\begin{array}{c}0.024^{* * *} \\
(0.006)\end{array}$ & & $\begin{array}{l}-0.003 \\
(0.025)\end{array}$ & & $\begin{array}{l}-0.003 \\
(0.023)\end{array}$ \\
\hline Top 11-25\% x Asian & & $\begin{array}{l}-0.003 \\
(0.012)\end{array}$ & & $\begin{array}{c}0.006 \\
(0.026)\end{array}$ & & $\begin{array}{c}0.189 * * * \\
(0.052)\end{array}$ \\
\hline \multicolumn{7}{|l|}{ College readiness } \\
\hline SAT percentile rank & $\begin{array}{c}0.956 * * * \\
(0.007)\end{array}$ & $\begin{array}{c}0.958^{* * *} \\
(0.007)\end{array}$ & $\begin{array}{c}0.795 * * * \\
(0.047)\end{array}$ & $\begin{array}{c}0.792^{* * *} \\
(0.047)\end{array}$ & $\begin{array}{c}-1.812^{* * *} \\
(0.052)\end{array}$ & $\begin{array}{c}-1.837 * * * \\
(0.051)\end{array}$ \\
\hline Exit exam percentile rank & $\begin{array}{c}-0.052^{* * *} \\
(0.007)\end{array}$ & $\begin{array}{c}-0.057 * * * \\
(0.007)\end{array}$ & $\begin{array}{c}-0.095 * * * \\
(0.022)\end{array}$ & $\begin{array}{c}-0.095^{* * *} \\
(0.022)\end{array}$ & $\begin{array}{c}0.115^{* * * *} \\
(0.018)\end{array}$ & $\begin{array}{c}0.120^{* * *} \\
(0.018)\end{array}$ \\
\hline AP semesters completed & $\begin{array}{c}-0.008^{* * *} \\
(0.000)\end{array}$ & $\begin{array}{c}-0.007 * * * \\
(0.000)\end{array}$ & $\begin{array}{c}-0.013 * * * \\
(0.001)\end{array}$ & $\begin{array}{c}-0.013^{* * *} \\
(0.001)\end{array}$ & $\begin{array}{c}0.010 * * * \\
(0.001)\end{array}$ & $\begin{array}{c}0.010^{* * *} \\
(0.001)\end{array}$ \\
\hline \multicolumn{7}{|l|}{ Other demographics } \\
\hline Female & $\begin{array}{c}0.008^{* * * *} \\
(0.002)\end{array}$ & $\begin{array}{c}0.008^{* * *} \\
(0.002)\end{array}$ & $\begin{array}{c}0.015 * * \\
(0.006)\end{array}$ & $\begin{array}{c}0.015 * * \\
(0.006)\end{array}$ & $\begin{array}{c}0.008 \\
(0.007)\end{array}$ & $\begin{array}{c}0.005 \\
(0.007)\end{array}$ \\
\hline Mother attended college & $\begin{array}{c}-0.014^{* * *} \\
(0.003)\end{array}$ & $\begin{array}{c}-0.014 * * * \\
(0.003)\end{array}$ & $\begin{array}{c}-0.023^{* * *} \\
(0.007)\end{array}$ & $\begin{array}{c}-0.023^{* * *} \\
(0.007)\end{array}$ & $\begin{array}{c}0.039 * * * \\
(0.007)\end{array}$ & $\begin{array}{c}0.039 * * * \\
(0.007)\end{array}$ \\
\hline
\end{tabular}


Family income ( $>\$ 80 \mathrm{k}$ is omitted)

\begin{tabular}{lcccccc} 
Less than $\$ 40 \mathrm{k}$ & $0.064^{* * *}$ & $0.063^{* * *}$ & $0.113^{* * *}$ & $0.113^{* * *}$ & $-0.063^{* * *}$ & $-0.061^{* * *}$ \\
& $(0.003)$ & $(0.003)$ & $(0.009)$ & $(0.009)$ & $(0.012)$ & $(0.012)$ \\
Between $\$ 40 \mathrm{k}$ to $\$ 80 \mathrm{k}$ & $0.054^{* * *}$ & $0.052^{* * *}$ & $0.083^{* * *}$ & $0.083^{* * *}$ & $-0.044^{* * *}$ & $-0.042^{* * *}$ \\
& $(0.003)$ & $(0.003)$ & $(0.007)$ & $(0.007)$ & $(0.012)$ & $(0.012)$ \\
& & & & & & \\
Observations & 93,860 & 93,860 & 25,842 & 25,842 & 18,066 & 18,066 \\
$\mathrm{R}^{2}$ & 0.222 & 0.224 & 0.135 & 0.136 & 0.134 & 0.151 \\
Other controls & & & & & & \\
High school fixed effects & Yes & Yes & Yes & Yes & Yes & Yes \\
\hline
\end{tabular}

Notes: Columns (1)-(6) show estimates from linear probability models of the probability of undermatch/overmatch in college enrollment. Undermatch occurs if the student's SAT score is more than 20 points above the lagged campus median. Overmatch occurs if the student's SAT score is more than 20 points below the lagged campus median. Robust

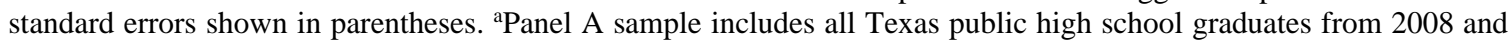
2009 who enrolled at a Texas public university (31 campuses) the following fall. banel B sample includes a subset of students with SAT scores (or ACT equivalent) in the top $25 \%$ among public university applications statewide. ${ }^{\text {cPanel C }}$ sample includes a subset of students with SAT scores (or ACT equivalent) in the bottom $25 \%$ among public university applications statewide. ${ }^{* *}, * *, *$ indicates statistical significance at the $1 \%, 5 \%$, and $10 \%$ level, respectively.

Source: Authors' calculations based on 2008 and 2009 student cohort data from the Texas Education Research Center (ERC) at the University of Texas at Austin. Our dataset includes Texas public high school graduates from spring 2008 and spring 2009 who also enrolled full-time at a Texas public university the following fall. This is approximately 20 percent of all graduates (from about 490,000 total high school graduates). The 2008 and 2009 high school graduates enrolled at one of 31 Texas public university including the elite flagship universities (University of Texas at Austin and Texas A\&M University at College Stations), other top 10\% campuses, and open enrollment institutions. 